\title{
Vuorimiehen velkainen elämä
}

\author{
Ismo Björn
}

Kristiina Kalleinen (2019) Nils Gustaf Nordenskiöld

- Vuorimiehen ja tiedemiehen elämä. Bidrag till

kännedom av Finlands natur och folk 208. Societas

Scientiarum Fennica. 223 sivua. ISBN 978-951-653-431-5

Kristiina Kalleisen kirjoittama Nils Gustaf Nordenskilöldin elämäkerta on ulkoisesti komea, kovakantinen, hyvälle paperille, värikuvin varustettu ja mallikkaasti taitettu kirja, jonka kuvituksessa on tuttua ja turvallista. Nykyaikaan nähden kirjassa on häpeämättömän miehinen ja kansallinen näkökulma. Otsikossa ovat sanat vuorimies ja tiedemies, takakannen esittelytekstissä kirjoitetaan Suomen mineralogian isästä ja geologian esi-isästä. Kirjan päähenkilö Nils Gustaf Nordenskiöld ei ole merkittävästä mineralogin urastaan huolimatta kuuluisan poikansa, tutkimusmatkailija Nils Adolf Erik Nordenskiöldin kaltainen kansallinen suurmies, eikä Kalleinen ole lähtenyt hänestä sellaista tekemään. Kalleinen lähestyy Nordenskiöldiä tämän oman kirjeenvaihdon ja julkisen elämän kautta. Keskiössä ovat miehen hallinnollinen ura ja rakkaus - tutkimukseen. Anekdootteja, hauskoja sattumuksia tai elämän suurta draamaa et tästä kirjasta löydä. Kalleinen tarkastelee kohdettaan kaukaa ja jättää Nordenskiöldin vaimon, lapset, perheen ja suvun taustalle. Tosin ne näyttävät jääneen toisarvoisiksi myös Nils Gustaf Nordenskiöldin omassa elämässä. Mies eli tieteessä, omissa verkostoissaan ja matkusti vuosikausia erossa perheestään. Vaimo Sofia Margaretha (von Haartman) sai Frugårdissa hoitaa talouden, kasvattaa lapset ja vanheta yksin miehensä taustalla ja jatkuvien velkojen painaessa.

Koska Kalleinen ei tavoittele inhimillistä Nordenskiöldiä, ei lukijakaan voi häneen samaistua. Kalleinen kertoo tiukasti lähteisiin perustaen ja niihin viitaten tieteellisten seurojen synnystä, ja siitä eurooppalaisesta verkostosta, jossa mineralogiaa Nordenskiöldin aikana synnytettiin. Kalleinen kirjaa tarkkoja päivämääriä ja mainitsee runsaasti nimiä. Kirja on melkoinen tietopaketti aikakautensa eurooppalaisista tiedemiehistä. Laajat sukuselvitykset ilahduttavat sukututkimuksesta ja säätyläisverkostoista innostuneita lukijoita. Kirjan henkilöhakemisto on kunnioitettava. Kirja on parhaimmillaan verkostokuvauksena. Nordenskiöldin suhdeverkosto oli niin laaja, että jonkinlainen verkostokartta tarvittaisiin sen ymmärtämiseksi.

Nordenskiöld oli yksilö, mutta hänet voi yleistää myös aikakautensa hahmona. Kirjaa saattaa siis lukea kuvauksena Suomen säätyläisten nopeasta käännöksestä Tukholmasta kohti Pietaria vuoden 1809 jälkeen. Säätyläiset niin Turussa kuin muualla Venäjän Ruotsilta valloittamilla alueilla ymmärsivät nopeasti Venäjän tarjoamat mahdollisuudet. Keskushallinto tarvitsi virkamiehiä, oikeuslaitos tuomareita. Kauppiaille ja teollisuudelle monikansallinen Venäjä tarjosi valtavat markkinat. Tieteessä Venäjä esiintyy kirjassa Suomen alus- tai siirtomaana. Näin kirja jatkaa eräänlaista suomalaisuuden rakentamista. 
Isänmaaksi muotoutuvan Suomen onni oli monen säätyläisen sanoin todella kuulua Venäjään. Kieli ei tuottanut ongelmaa, sillä säätyläiset hallitsivat vähintään saksan, monet myös ranskan, ja näillä tultiin valtioiden rajat ylittävässä sääty-yhteisössä toimeen. Saksa oli pitkään tieteen kieli myös Venäjällä. Nils Gustaf Nordenskiöld oli yksi heistä, jotka arvostelivat Ruotsiin kallellaan olevia ja sieltä rautaa tuovia ruukinpatruunoita epäisänmaallisiksi. Hänen pojastaan Nils Adolf Erik Nordenskiöldistä tuli ruotsalainen, sillä hänen ajattelussaan havaittiin Venäjää ja tsaarin valtaa arvostelevia sävyjä. Isä itse piti tarkkaan huolen, että ei puhunut politiikkaa. Arvoitukseksi jää, miten Nordenskiöld ymmärsi muotoutuvan Suomen ja oman asemansa siinä Venäjän hallinnon määrittelemässä todellisuudessa, jossa hän eli ja toimi. Mikä oli Nordenskiöld todella miehiään? Mitä hän ajatteli Suomesta, perheestä ja yhteiskunnasta?

Nordenskiöldin suku antaa jotain viitteitä, jotka ohjasivat Nils Gustafin elämää. Suvulle yhteistä näyttää olleen kiinnostus tieteeseen ja yhteiskunnalliseen ajatteluun sekä taipumus mystiikkaan. Nils Gustaf Nordenskiöld pysytteli tietoisen tarkasti erossa yhteiskunnallisesta ajattelusta, mutta Nordenskiöldin suvun kaikki ominaisuudet yhdistyivät etenkin 1792 kuolleessa August Nordenskiöldissä. Kalleinen esittelee hänet alkemistina ja utopistina. Maailmalla mies tunnetaan orjuuden vastustajana, joka tavoitteli kaikkien rotujen tasa-arvoa. Nils Gustaf edusti toista ääripäätä, sillä hän ei näytä lainkaan huomioineen Venäjällä vallitsevaa maaorjuutta ja tavallisen kansan raatamista. August Nordenskiöldin puolustukseksi on puolestaan todettava, että nykyisin pseudotieteenä pidetty alkemia oli hänen aikakautenaan vakavasti otettu tutkimusala, johon kannatti panostaa.

Kalleisen valinta hieman etäiseen lähestymistapaan kirjansa päähenkilöön on ymmärrettävää, sillä Nils Gustaf Nordenskiöldin elämä ei ollut esimerkillinen, eikä hän näytä eläneen sellaisten moraalisten arvojen mukaan, mitä ylipäätään tulisi seurata. Hän ei noussut vaikeuksien kautta huipulle, kuten suurmieselämäkerroissa usein kerrotaan. Nordenskiöld eli veloissa ja veloissaan hän kuoli. Kirjeiden ja aikalaiskuvausten perusteella miehestä jää hieman valju kuva. Mies oli "jokseenkin harmiton”, eikä myöskään Kalleinen ylistä kohdettaan. Nordenskiöld vaikuttaa olleen arkielämässä tarmoton ja toimeton tyyppi. Hän viihtyi laboratoriossa ja maailmalla tiedemiespiireissä. Perhe sai tulla toimeen miten kykeni. Kalleinen kirjoittaa useaan kertaan Nordenskiöldin elämisestä yli varojensa, mutta hän ei tarkemmin erittele, mistä lopulta oli kyse. Pyrkikö Nordenskiöld noudattamaan säätyasemansa normia, vai oliko kyse pelkästään taitamattomuudesta ja saamattomuudesta.

Kristiina Kalleinen on historiantutkija, joka perustaa tekemisensä lähdeaineiston varaan. Pääsy Fiskarsiin ja von Julinin yksityisarkiston kirjeisiin on kirjan kannalta ollut ensiarvoisen tärkeää. Säilyneen kirjeenvaihdon tarkka selvittäminen sisältöjä myöten tekee kirjasta ajoittain raskaan. Osa teksteistä on mukana lähes sellaisenaan suomeksi käännettyinä, osa jopa siten, että alkuperäisen kirjeen tönkkö tyyli on edelleen mukana. Kirjeistä paljastuu henkilökohtaisia kaunoja, juonitteluja ja ylempien mielistelyä. Kalleinen ei astu oman asiantuntemuksensa ulkopuolelle, eikä pohdi tarkemmin kirjeiden kohteita ja sitä, miten se, kenelle kirjoittaa, on vaikuttanut kirjeiden sisältöön.

Kalleinen ei lähde tekemän rohkeita vetoja ja yleistämään. Hän jättää lukijalleen pohdinnan esimerkiksi siitä, mitä kansalliset herätykset niin Suomessa kuin Venäjällä ja eurooppalaisen verkoston vähittäinen hajoaminen tarkoittivat. Tekniikan historiasta kiinnostunut lukija jää kaipaamaan tietoja Nordenskiöldin patenttiyrityksistä ja hänen tekemistään teknisistä parannuksista esimerkiksi kuparin tuotannon kehittämisessä. Kiinnostavaa olisi tietää, miten uunit toimivat, ja oliko Nordenskiöldin tekemillä muutoksilla todella arvoa. 
Nykypäivän lukija lukee Nordenskiöldin maailmasta omaa aikakauttaan. Analogia nykyiseen tiedemaailmaan on ilmeinen. Myös tänään tutkijan työtä hallitsevat samat matkalupien ja rahoitusten hakemiset kuin Nordenskiöldin aikana. Tutkijat joutuvat selittämään rahakirstujen vaalijoille, miksi olisi tärkeä matkustaa. Verkostoitumisen tärkeys, raportointi, tieteen hyödyn esittäminen sovellettavuutena, innovaatiot ja talouden edistäminen ovat myös nykypäivän tutkimusmaailman puhetta. Nordenskiöldin aikana kilpailtiin mineraalien kuvauksista ja siitä, kuka ehtii julkaista missäkin. Nyt kilpaillaan tutkimusten määrillä ja julkaisufoorumeilla. Yhteistä on myös rahoittajien mielistely ja jatkuva rahahakemusten teko. Rivien välistä on luettavissa paljon sanomatonta. 